\title{
STRATEGI PEMASARAN TABUNGAN PADA PT. BANK PERKREDITAN RAKYAT RANGKING AUR
}

\author{
Putri Gusti Rahayu, Mariani St.B Tanjung \\ Akademi Keuangan dan Perbankan Padang \\ mstbtanjung@gmail.com
}

\begin{abstract}
ABSTRAK
Tujuan dari penelitian ini adalah untuk mengetahui lebih jauh Strategi Pemasaran Tabungan Pada PT. Bank Prekreditan Rakyat Rangkiang Aur. Metode Analisa Data yang digunakan metode analisa kualitatif sebagai metode penelitian yang menjelaskan secara deskriptif mengenai Pemasaran Tabungan Pada PT. Bank Prekreditan Rakyat Rangkiang Aur. Kesimpulan 1) Dengan strategi pemasaran yang terencana dan terarah maka PT. BPR Rangkiang Aur melakukan kebijaksanaan dalam pemasaran dengan menggunakan strategi pemasaran yang meliputi tentang Produk, Price, Place, Promotion, People, Proces, Customer Service. Serta tingkat suku bunga yang sesuai dengan ketentuan yang berlaku dan memberikan undian berhadiah sebagai bagian dari promosi. 2) PT. BPR Rangkiang Aur melakukan Promosi jenis periklanan dalam bentuk brosur-brosur, pemasangan spanduk dan pemasangan baliho, serta souvenir-sovenir pada nasabah guna meningkatkan penabung dan jumlah tabungan.
\end{abstract}

Kata Kunci: Strategi Pemasaran

\section{PENDAHULUAN}

Pertumbuhan ekonomi suatu bangsa memerlukan pola pengaturan, pengelolahan sumber-sumber ekonomi yang tersedia secara terpadu dan terarah serta diarahkan bagi peningkatan kesejahteraan masyarakat. Lembaga-lembaga perekonomian bahu-membahu mengelola dan mengerakkan semua potensi ekonomi agar berdaya guna secara optimal. Lembaga keuangan khususnya lembaga perbankan mempunyai peranan yang sangat strategis dalam menggerakan roda perekonomian suatu negara. Bankir-bankir yang mengelola banknya menurut system dan metode yang memacu produktifitas usaha para nasabah akan mampu melihat kedepan dan mengambil keputusan yang gemilang bagi perkembangan perekonomian negara. Salah satu faktor yang mendorong untuk terwujudnya dan kelancaran pembangunan tersebut adalah faktor ekonomi dan lajunya faktor perekonomian yang didukung oleh berbagai faktor pula, salah satunya laju tindakannya pembayaran uang didalam masyarakat. Semakin cepat uang beredar semakin cepat laju perekonomian negara tersebut.

Dalam peredaran uang dalam masyarakat, diperlukan adanya alat perlengkapan yang potensial dan efektif untuk mengendalikan peredaran uang, 
dimana sebagian alat perlengkapan tersebut dapat dilakukan melalui suatu badan atau lembaga keuangan misalnya Lembaga Keuangan Bank, Lembaga Keuangan bukan Bank. Sebagaimana tercantum dalam UU Perbankan Tahun 1998 yang dimaksud dengan Bank adalah usaha yang menghimpun dana dari masyarakat yang dalam bentuk simpanan dan menyalurkan pada masyarakat dalam bentuk kredit.

PT. Bank Perkreditan Rakyat Rangking Aur sebagai salah satu lembaga keuangan di Bukittingi memegang peranan penting dalam pembangunan yang menyediakan jasa-jasa dalam pemberian kredit juga menerima simpanan dari masyarakat berupa tabungan. Dalam aktivitas pemasaran tabungan, PT. BPR Rangkiang Aur menggunakan kebijakan pemasaran yang dilakukan dengan menggunakan beberapa elemen Marketing Mix yaitu produk, price, place, promotion, people, process, custumer service. Untuk membantu penjualan produk atau jasa bank dengan tujuan menghimpun dana masyarakat sebanyak banyaknya.

Dalam penulisan penelitian penulis membatasi strategi pemasaran hanya untuk produk tabungan. Produk tersebut merupakan produk simpanan masyarakat yang mempengaruhi aktivitas dana-dana pada PT.BPR Rangkiang Aur. Untuk meningkatkan penjualan produk simpanan maka, PT. BPR melakukan strategi pemasaran yang tepat. Berdasarkan pada uraian diatas maka penulis tertarik untuk membahas lebih jauh dalam bentuk penelitian yang berjudul "Strategi Pemasaran Tabungan Pada PT. Bank Prekreditan Rakyat Rangkiang Aur"

\section{LANDASAN TEORI}

Defenisi dan Fungsi Bank

Ada dua macam masyarakat yang berhubungan dengan bank yaitu para nasabah dan masyarakat umum. Para nasabah adalah masyarakat yang mempunyai kepentingan langsung dengan bank. (Sumarni : 162)

Bank adalah badan usaha yang menghimpun dana dari masyarakat dalam bentuk simpanan dan menyalurkan dalam bentuk kredit atau bentuk-bentuk lainnya dalam rangka meningkatkan taraf hidup orang banyak. (Kasmir $2001: 23$ )

Menurut Sinungan (1993:3) bank adalah suatu lembaga keuangan, yaitu suatu badan yang berfungsi sebagai perantara dari dua pihak, yakni : pihak yang kelebihan dana dan pihak yang kekurangan dana.

Dari pengertian diatas dapat dijelaskan secara lebih luas bahwa bank merupakan perusahaan yang bergerak dibidang keuangan, artinya perbankan selalu berkaitan dalam bidang keuangan. Berdasarkan defenisi mengenai bank dapat dinyatakan fungsi bank sebagai berikut :

1. Sebagai lembaga penghimpun dana masyarakat.

2. Sebagai lembaga yang menyalurkan dana kepada masyarakat dalam bentuk kredit dan sebagai lembaga pemberian kredit.

3. Sebagai lembaga yang melancarkan transaksi perdagangan dan pembayaran hutang. 


\section{Defenisi Pemasaran}

Pemasaran merupakan jantung atau penentu hidup matinya sebuah perusahaan dan sebagai ujung tombak atau kunci dalam pemasaran barang atau prouduk yang dihasilkan kepada konsumen

Pemasaran adalah suatu system keseluruhan dari kegiatan bisnis yang ditunjuk untuk merencanakan, menentukan harga produksi dan mendistribusikan barang dan jasa yang memuaskan kebutuhan bank kepada pembeli yang ada maupun pembeli yang potensial.(Kasali: 2002)

Pemasaran adalah menciptakan layannan yang memuaskan nasabah di suatu pihak dan menguntungkan bank dipihak lain. (Simorangking, 1998:37)

Dari defenisi beberapa ahli diatas maka dapat diambil kesimpulan bahwa pemasaran merupakan suatu kegiatan bisnis untuk memuaskan kebutuhan manusia baik produsen maupun konsumen. Kepuasan berarti membeli barang dengan harga yang tepat dan bermanfaat melalui penggunaan barang dan jasa tersebut, sedangkan kepuasan produsen berarti keuntungan yang diperoleh dengan memgusahakan adanya pengeluaran biaya tertentu untuk memproduksi barang dan jasa serta menyalurkannya kepada konsumeen dengan cara yang tepat dan bermanfaat, yang mengakibatkan terjadinya penawaran.

\section{Strategi Pemasaran}

Strategi pemasaran berkaitan dengan masalah bagaimana menetapkan bentuk penawaran pada segmen pasar tertentu. Hal ini dapat terpenuhi dengan penyediaan suatu sarana yang disebut bauran pemasaran yang merupakan inti dari system pemasaran bank. Menurut Sumarni (1993 :15) mengemukan pemasaran adalah kegiatan manusia yang diarahkan untuk memuaskan kebutuhan dan keinginan melalui proses pertukaran.

Untuk dapat menunjang peningkatan jumlah nasabah atau konsumen maka diperlukan suatu strategi pemasaran yang tepat dan terarah sebagai berikut:

1. Strategi Berdasarkan Segmentasi Pasar

Yaitu dengan membagi pasar kedalam kelompok-kelompok sejenis dan memilih yang paling sesuai bagi bank dalam upayanya memberikan pelayanan yang terbaik dan menarik bagi nasabah. Misalnya untuk kelompok pengusaha di perkenalkan giro dan untuk pengajar diperkenalkan tabungan.

2. Strategi Pemasaran Berdasarkan Market Positioning

Yaitu dengan menambah ciri-ciri tertentu bagi produk-produk antara lain memudahkan persyaratan menabung dan penarikan tabungan serta memberikan tingkat bunga yang tetap bersaing dengan tingkat bunga pasar.

3. Strategi Berdasarkan Struktur Pasar

Bagi suatu perusahaan sebelum menawarkan dan memasarkan, biasanya terlebih dahulu harus mengetahui peluang dan potensi pasar tersebut, maka perusahaan akan dapat memperkirakan tingkat penjualan yang akan dicapai. Salah satu cara untuk melihat peluang 
dan potensi tersebut yaitu dengan mempelajari struktur pasar ini merupakan pedoman dalam menyusun strategi dalam menghadapi persaingan.

Strategi untuk menetapkan keputusan yang berhubungan dengan pemasaran adalah strategi produk. Strategi produk dipakai oleh perusahaan untuk mengubah atau menyempurnakan produk yang ada sekarang menjadi bentuk yang lebih baik. Sehingga produk perusahaan tidak kalah dengan produk milik pesaing dan sesuai dengan kebutuhan dan selera konsumen.

Selain strategi produk, strategi promosi juga merupakan suatu bagian yang sangat penting. Promosi adalah suatu cara langsung untuk mempengaruhi konsumen agar labih suka membeli merek barang tertentu. Untuk strategi harga pada umumnya bank menetapkan harga (bunga) dengan berbagai tujuan yaitu:

1. Memperoleh laba maksimal, bank menentukan harga sendiri dengan tujuan memperoleh laba secara maksimal.

2. Bank menetapkan suatu kebijakan harga yaitu menentukan harga yang sama kepada semua konsumen dan dalam jumlah yang sama.

Sebagaimana halnya produk jasa memerlukan pendistribusian agar dapat sampai ketangan konsumen. Sebagaimana halnya dengan pemasaran barang atau jasa, bank harus jelas mengambarkan pemasarannya, mengetahui struktur pasar / komponen kependudukan dan pendapatan konsumen, karena merekalah yang mempengaruhi pasar.

\section{Bauran Pemasaran (Marketing Mix)}

Defenisi marketing mix menurut (Lupioyadi, 2001:58) merupakan tool atau alat bagi marketer yang terdiri dari berbagai elemen program pemasaran yang diperlu diterapkan dapat berjalan sukses.

Agar dapat melakukan penghimpunan dana masyarakat, bank memerlukan adanya suatu strategi pemasaran yang baik. Strategi pemasaran berkaitan dengan masalah bagaimana menetapkan bentuk penawaran pada segmen pasar tertentu. Hal ini dapat terpengaruhi dengan penyediaan sarana yang disebut bauran pemasaran yang merupakan inti dari pemasaran bank.

\section{Produk (Product)}

Elemen-elemen yang bias digunakan dalam perusahaan jasa (bank) yaitu:

Pengertian produk menurut (Staton, 1995 : 222) adalah sekumpulan atribut yang nyata dan didalamnya sudah tercangkup warna, harga, kemasan yang mungkin diterima oleh pembeli sebagai sesuatu yang bisa memuaskan keinginannya. Yang perlu diperhatikan menyangkut produk adalah konsumen tidak hanya membeli fisik dari suatu produk tetapi membeli benefit (manfaat) dan value (nilai tambah) dari suatu produk (lupioyadi, 2001)

\section{Price (Harga)}

Yang harus diperhatikan disini adalah bahwa harga produk bank tidak dapat diukur dari bunga semata tetapi juga dari kepuasan nasabah dan bank. Dengan demikian penetapan harga dan pihak bank harus dihubungkan.

a) Bagaimana nasabah menerima harga produk yang ditawarkan oleh bank.

b) Bobot subjektif dari kedua belah pihak. 
Pengertian harga menurut Statoon (1995:306) adalah jumlah uang yang dibutuhkan untuk memperoleh beberapa kombinasi sebuah produk dan pelayanan yang menyertai.

\section{Place (Jaringan Kerja)}

Jaringan kerja untuk dapat mencapai sasaran produk dan jasa bank maka diupayakan agar selalu dekat dengan nasabah untuk menjalin hubungan antara nasabah dengan bank dan juga bank menawarkan adanya suatu jaringan kerja yang cukup. Menurut Lupioyadi (2001:61) merupakan gabungan antara lokasi dan kepuasan atas saluran distribusi, dalam hal ini berhubungan dengan bagaimana cara penyampaian jasa kepada konsumen dan dimana terjadinya.

\section{Promotion (Promosi)}

Promosi bukan saja untuk perusahaan yang memproduksi barang fisik tetapi juga sangat penting bagi perusahaan yang bergerak dibidang jasa. Pada perusahaan jasa kegiatan promosi sangat penting dan berarti sekali karena yang mereka tawarkan adalah jasa yang merupakan produk yang tidak berwujud atau abstrak.

Program promosi pada perusahaan jasa mempunyai tujuan yaitu:

1. Menggambarkan manfaat jasa-jasa secara paling menarik

2. Membuat tawaran yang mudah dibebankan dari tawaran pesaing.

Program promosi yang melalui periklanan, komunikasi non personal dengan sejumlah biaya, melalui berbagai media yang dilakukan oleh fungsi-fungsi periklanan:

1. Memberi informasi

2. Membujuk atau mempengaruhi

3. Menciptakan kesan (image)

4. Memuaskan keinginan

Menurut Kotler (2000), untuk dapat membantu penjualan produk atau jasa secara umum dapat digunakan melalui media komunikasi yang tercangkup dalam bauran promosi:

\section{a. Periklanan}

Promosi melalui iklan merupakan kegiatan yang sangat penting dalam menawarkan produk dan jasa suatu perusahaan, kepada sekelompok masyarakat secara lisan maupun tulisan.

b. Personal Selling (Penjualan Secara Pribadi)

Kebijaksanaan personal selling dilakukan dengan cara menugaskan karyawan untuk langsung mempromosikan produk-produk bank kepada masyarakat seperti sekolah-sekolah, pegawai negri, pedagang dan petani. Personal selling memiliki sejumlah keuntungan yang melebihi elemen promosi dan komunikasai yang lain:

1. Personal selling merupakan bentuk komunikasi dua arah yang memberikan peluang bagi calon pembeli untuk menanyakan produk atau jasa pada personal selling.

2. Pesan penjual dapat dibuat secara fleksibel dan oleh karena itu dapat disesuaikan dengan kebutuhan pelanggan.

3. Personal selling dapat menggunakan pengetahuan produk dan jasa secara mendalam untuk menghubungkan pesannya dengan kebutuhan yang dirasakan oleh pembeli dan untuk menangani keluhan-keluhan yang dirasakan pelanggan. 
c. Promosi Penjualan

Kegiatan pemasaran yang mendorong efektifitas pembelian konsumen dan pedagang dengan menggunakan alat peragaan, pameran, demonstrasi, hadiah dan sebagainya.

d. Hubungan Masyarakat dan Publikasi.

Publisitas merupakan bagian dari sebuah konsep yang lebih luas yaitu hubungan masyarakat berfungsi sebagai manajemen yang memberikan tentang sikap masyarakat, identitas kebijaksanaan prosedur dari individu atau organisasi dengan keinginan masyarakat.

\section{People (orang yang berkualitas yang terlibat dalam pemasaran)}

Reaksi dari nasabah akan mutu dan bentuk pelayanan dari bank dimana akan mempengaruhi citra produk bagi kedua belah pihak. Tingkat pengetahuan dan pendidikan nasabah dapat mempengaruhi selera atau permintaannya, dengan demikian pihak bank memerlukan petugas yang:

1. Peka atas nasabah

2. Menjiwai kebutuhan pasar

3. Tampil dalam penjualan

4. Mampu berkomunikasi dengan prima.

6. Process (Bagaimana Proses atau Prosedur dalam Kegiatan Operasional)

Proses merupakan semua gabungan aktivitas yang terdiri dari prosedur pelaksanaan, mekanisme kerja, aktivitas, dan hal-hal lain yang rutin. Dimana jasa dihasilkan kepada konsumen. Lupioyadi (2001 : 64 ).

\section{Customer Service (Pelayanan yang di berikan kepada nasabah)}

Customer service jasa dapat dilihat sebagai outcome dari kegiatan distribusi, dimana pelayanan diberikan kepada nasabah untuk memberikan kepuasan. Customer service meliputi aktifitas untuk memberikan kegunaan waktu dan tempat, termasuk pelayanan pra transaksi dan pasca transaksi. Kegiatan sebelum transaksi akan turut mempengaruhi kegiatan saat transaksi dan setelah transaksi. Oleh karena itu kegiatan pendahuluannya harus sebaik mungkin, sehingga konsumen memberikan respon yang positif dan menunjang loyalitas yang tinggi.

\section{ANALISA DAN PEMBAHASAN}

\section{Bauran Pemasaran yang dilakukan Oleh PT. BPR Rangking Aur}

Menurut Sinungan (1993) tabungan adalah, simpanan yang penarikannya hanya dapat dillakukan menurut syarat-syarat yang disepakati, tetapi juga dapat ditarik dengan cek atau alat yang dapat dipersamakan dengan itu.

Agar penghimpunan dana dalam bentuk tabungan dapat meningkat dari tahun ketahuan PT. BPR Rangkiang Aur menerapkan kegiatan pemasaran Bank yang terencana dan tearah. Karena menyadari bahwa nasabah mau memanfaatkan produk yang ditawarkannya apabila produk tabungan tersebut memberi keuntungan baginya.Misalnya keuntungan dan kualitas yang baik. Serta pelayanan yang diberikan oleh bank atas pemakaian produk tabungan tersebut.

Pada PT.BPR Rangking Aur menggunakan kebijaksanaan pemasaran yang terdiri dari kebijaksanaan produk, harga, promosi, tempt (distribusi), orang (karyawan), proses (alur Kerja), layanan pelanggan. 


\section{Product ( produk)}

Jenis-jenis produk tabungan pada PT.BPR Rangking Aur yaitu :

1. Tabungan BPR

Merupakan tabungan untuk umum yang bunganya lebih tinggi dari tabungan Niagara, bunga dihitung berdasarkan saldo terendah.

2. Tabungan Niagara

Merupakan tabungan untuk para pedagang yang bunganya dihitung perhari, semakin tinggi jumlah tabungan maka semakin tinggi pula bunga yang di dapatkan.

3. Tabungan Anak Nagari (TAN)

Merupakan tabungan untuk umum yang bunganya lebih rendah, tetapi nasabah Tabungan Anak Nagari ini diikutkan undian.

4. Tabungan Modal Kerja (TAMORA)

Merupakan tabungan khusus untuk nasabah kredit, tetapi saldo minimal tabungan harus sama besarnya dengan angsuran perbulan debitur.

Setiap jenis tabungan akan diberikan bunga tabungan. Bunga tabungan di perhitungkan setiap akhir bulan berdasarkan saldo terendah pada bulan bersangkutan dan pada awal berikutnya langsung menambah saldo tabungan

Dalam rangka menarik minat masyarakat dalam menabung pada PT. BPR Rangkiang Aur, maka PT. BPR Rangkiang Aur melakukan kebijaksanaan yaitu:

Penyetoran dapat dilakukan secara tunai atau pemindah bukuan dari deposito dan bunga deposito, droping kredit serta transfer dari bank lain, dimana bank akan mengadministrasikan pada buku tabungan. Rekening tabungan hanya dapat dibuka apabila kebenaran dan kelengkapan dokumen telah diperiksa, serta telah disetujui oleh pimpinan yang menandatangani buku tabungan.

Tabungan pada PT. BPR Rangkiang Aur suatu tempat dimana masyarakat dapat menarik dana yang disimpan dan setelah jatuh tempo perjanjian dan digunakan untuk kegiatan usaha atau di tabung. Setiap tabungan dari masyarakat dikembalikan dalam bentuk pinjaman ataupun kredit pada masyarakat dan setiap tabungan diberi bunga.

Untuk melihat perkembangan jumlah tabungan dapat dilihat pada table 1 berikut :

Tabel 1

Perkembangan Jumlah Penabung Dan Jumlah Tabungan

Tahun 2007-2011

\begin{tabular}{|c|c|c|}
\hline Tahun & $\begin{array}{c}\text { Jumlah Penabung ( } \\
\text { orang ) }\end{array}$ & Jumlah Tabungan ( Rp ) \\
\hline 2007 & 4933 & 3.154 .581 .000 \\
\hline 2008 & 4962 & 3.324 .964 .000 \\
\hline 2009 & 4689 & 3.202 .549 .000 \\
\hline 2010 & 4798 & 3.215 .588 .000 \\
\hline 2011 & 4889 & 3.308 .598 .000 \\
\hline
\end{tabular}

Sumber : PT. BPR Rangkiang Aur 
Perkembangan jumlah penabung pada PT. BPR Rangkiang Aur dari tahun 2007-2011, mengalami fluktuasi naik turun, dapat dilihat dari tabel 1 . Perkembangan jumlah penabung dari tahun 2007-2008 mengalami peningkatan sebanyak 29 orang. Pada tahun 2008-2009 mengalami penurunan sebanyak 273 orang. Pada tahun 2009-2010 mengalami peningkatan sebanyak 109 orang. Pada tahun 2010-2011 mengalami peningkatan 91 orang.

Perkembangan jumlah tabungan pada PT. BPR Rangkiang Aur dari tahun 2007-2011,juga mengalami fruktuasi naik turun. Dilihat pada jumlah tabungan dari tahun 2007-2008 mengalami peningkatan sebesar Rp.170.383.000,-. Pada tahun 2008-2009 mengalami penurunan sebesar Rp.122.415.000,-. Pada tahun 2009-2010 mengalami peningkatan sebesar Rp.13.039.000,-. Dan pada tahun 2010-2011 mengalami peningkatan sebesar Rp.93.010.000,-.

Dari penjelasan diatas, secara garis besar terlihat jumlah penabung dan jumlah tabungan meningkat namun terjadi penurunan pada tahun 2009. Menurunnya jumlah penabung dan jumlah tabungan pada tahun 2009 diakibatkan karena, pada tahun 2009 daerah Sumatra Barat mengalami gempa bumi yang mengakibatkan lumpuhnya sektor ekonomi, sehingga kurangnya kemampuan para penabung dalam berinvestasi.

\section{Price (Harga)}

Harga yang berlaku pada bank berupa bunga yang ditetapkan pada perkembangan tingkat bunga tabungan. Untuk mengetahui perkembangan tingkat bunga tabungan PT. BPR Rangkiang Aur dapat dilihat dari table 2.

\section{Tabel 2}

\section{Perkembangan Tingkat Suku Bunga Tabungan}

PT. BPR Rangkiang Aur

Tahun 2007-2011

\begin{tabular}{|c|c|c|}
\hline \multirow{2}{*}{ Tahun } & \multicolumn{2}{|c|}{ Tabungan } \\
\cline { 2 - 3 } & Tingkat Bunga ( \%) & Perubahan ( \%) \\
\hline 2007 & 5 & 0 \\
\hline 2008 & 5 & 0 \\
\hline 2009 & 5 & 0 \\
\hline 2010 & 5 & 0 \\
\hline 2011 & 5 & 0 \\
\hline
\end{tabular}

Sumber : PT. BPR Rangkiang Aur

Dari table 2 dapat diketahui bahwa tingkat suku bunga pada PT. BPR Rangkiang Aur dari tahun 2007 sampai dengan tahun 2011 tidak mengalami perubahan setiap tahunnya, yaitu sebesar $5 \%$.

\section{Place (Jaringan Kerja)}

Dalam menjalankan kegiatan usahanya yaitu strategi pemasaran produk tabungan, PT. BPR Rangkiang Aur melakukan kegiatan operasional yang lokasi kantor di Jln. Belakang Pasar Aur Kuning No. 9 Bukittinggi. PT. BPR Rangkiang Aur ini dinilai strategis karena dekat dengan pasar, pedagang-pedagang pasar dan penduduk setempat.

\section{Promotion (Promosi)}

Dalam strategi pemasaran tabungan, PT. BRP Rangkiang Aur melakukan kebijaksanaan promosi dengan cara sebagai berikut: 
a. Periklanan

PT. BPR Rangkiang Aur melakukan kegiatan periklanan melalui brosur, dan papan reklame. Brosur-brosur yang mengenai aktivitas dan jasa yang ditawarkan, disebarkan kepada masyarakat guna menarik perhatian dan keinginan mereka untuk meningkatkan minat masyarakat untuk menabung di PT. BPR Rangkiang Aur. Serta pemasangan spanduk ditempat-tempat yang strategis, seperti di pasar, di jalan raya dan lain-lain.

b. Promosi Penjualan

Kebijakan promosi penjualan dilakukan dengan cara penarikan undian berhadiah untuk masyarakat yang menabung pada PT. BPR Rangkiang Aur dengan memberikan hadiah-hadiah, kalender, gantungan kunci, buku agenda dan alat tulis yang semuanya bersimbol BPR Rangkiang Aur, dengan harapan para nasabah atau masyarakat selalu mengingat dan terarik pada PT. BPR Rangkiang Aur.

Jadi sasaran utama bank dalam melakukan promosi penjualan ini adalah untuk menyadarkan calon nasabah tentang adanya keuntungan yang diperoleh oleh jasa-jasa yang ditawarkan serta mendorong nasabah meningkatkan penggunaan suatu produk bank.

c. Penjualan Pribadi

Penjualan pribadi (Personal selling) dilakukan dengan cara menugaskan karyawan untuk langsung mempromosikan produk tabungan kepada masyarakat seperti sekolah-sekolah, pegawai negri, pedagang dan masyarakat disekitarnya.

d. Publisitas

Merupakan promosi yang dilakukan untuk meningkatkan citra bank didepan calon nasabah atau nasabahnya melalui kegiatan sponsorship terhadap suatu kegiatan amal, sosial, dan olahraga.

e. Promosi Langsung

Promosi jenis ini dalam penggunaanya menggunakan surat, telepon, faksimail, e-mail, dan alat penghubung nonpersonal lain untuk berkomunikasi secara langsung dengan mendapatkan tanggapan langsung dari pelanggan tertentu dan calon pelanggan.

\section{People (Orang yang berkualitas yang terlibat dalam pemasaran)}

Karyawan merupakan hal yang sangat menentukan berjalannya kegiatan operasional PT. BPR Rangkiang Aur dalam pemasaran produk tabungan.

\section{Process (Alur Kerja)}

PT. BPR Rangkiang Aur memberikan kemudahan, kecepatan, ketelitian pada saat transaksi dengan nasabah. Misalnya menerima nasabah dalam hal membuka rekening tabungan, dengan cara kerja yang cepat, akan menciptakan proses kerja

yang tidak membuat nasabah lama menunggu. Dan juga dalam hal penarikan uang, bank dengan cepat prosesnya.

Agar dapat memberikan kepuasan pada nasabah yang menabung di PT. BPR Rangkiang Aur maka PT. BPR Rangkiang Aur menerapkan kebijaksanaan tabungan yaitu : 
1) Nasabah membuka rekening tabungan dengan melakukan penyetoran awal dengan jumlah minimal setoran awal Rp. 20.000,- kemudian nasabah akan menerima buku tabungan.

2) Jika nasabah ingin menambah rekening tabungan maka bank akan mendebitkan rekening tersebut.

\section{Costumer Service (layanan pelanggan)}

Untuk meningkatkan pelayanan pada masyarakat atau nasabah, maka PT. BPR Rangkiang Aur melakukan hal-hal sebagai berikut :

1) Mediakan tempat/kantor dan ruang tunggu yang memadai, dengan tata ruang yang nyaman sehingga nasabah merasa nyaman bila memasuki kantor BPR Rangkiang Aur.

2) Memberikan pelayanan yang memadai untuk kepentingan nasabah.

3) Adanya satpam yang mendapat memberikan kondisi aman di bank.

Hambatan yang dialami PT. BPR Rangkiang Aur dalam mengembangkan produk tabungan

Walaupun perkembangan PT. BPR Rangkiang Aur cukup baik, tetapi dirasakan masih ada hambatan-hambatan bagi BPR Rangkiang Aur dalam mengembangkan produk tabungannya.

Hambatan-hambatan yang dirasakan oleh PT. BPR Rangkiang Aur antara lain sebagai berikut :

1) Adanya masalah-masalah tertentu yang diragukan dan terpaksa melakukan konsultasi dengan atasannya. Kemudian kurangnya keterampilan karyawan hanya dapat pada karyawan tertentu saja.

2) Kurangnya Pengetahuan Masyarakat

Khususnya mengenai bank, mengakibatkan masyarakat sering tertipu oleh ulah rentenir dengan menggunakan system ijon yang menawarkan bunga

yang tinggi dengan prosedur yang mudah, murah dan dilakukan kapan saja.

Sedangkan kebijaksanaan yang diambil oleh PT. BPR Rangkiang Aur dalam mengatasi masalah-masalah tersebut adalah :

a) PT. BPR Rangkiang Aur menyebarkan brosur yang menginformasikan tentang perbankan khususnya tentang PT. BPR Rangkiang Aur.

b) Mengadakan penyuluhan-penyuluhan yang dilakukan oleh pegawai bank yang telah dibina, penyuluhan ini dilakukan diforum kemasyarakatan.

Kegiatan PT. BPR Rangkiang Aur untuk mempererat hubungan dengan calon penabung

PT. BPR Rangkiang Aur adalah salah satu bank yang mempunyai hubungan dengan calon penabung. Dimana pengertian dan kepercayaan calon penabung tidak ternilai harganya.

Usaha-usaha bank untuk lebih mempererat hubungan dengan calon penabung atau nasabah adalah :

1. Pihak perbankan melaksanakan sarana promosi yang menyenangkan dari calon penabung berupa iklan yang melalui pemasangan spanduk pada 
halte-halte bus, pemasangan baliho, dan perangsang iklan lainnya. Perangsang itu

diantaranya bunga tabungan, bebas pajak kekayaan atas pokok tabungan dan sebagainya.

2. Pejabat atau petugas bank tidak boleh berlaku kasar terhadap calon pyenabung yang akan menyimpan uang dibank.

3. Lembaga perbankan memberikan penyuluhan pada calon penabung tentang cara-cara menabung yang produktif, serta dengan keamanan yang terjamin sepenuhnya.

Dengan adanya kegiatan atau usaha-usaha bank ini maka dana calon penabung dapat terhimpun semakin meningkat, ini merupakan suatu pertanda bahwa kepercayaan para penabung untuk menyimpan uangnya pada PT. BPR Rangkiang Aur semakin mantap.

\section{PENUTUP}

\section{Kesimpulan}

1. Dengan strategi pemasaran yang terencana dan terarah maka PT. BPR Rangkiang Aur melakukan kebijaksanaan dalam pemasaran dengan menggunakan strategi pemasaran yang meliputi tentang Produk, Price, Place, Promotion, People, Proces, Customer Service. Serta tingkat suku bunga yang sesuai dengan ketentuan yang berlaku dan memberikan undian berhadiah sebagai bagian dari promosi.

2. PT. BPR Rangkiang Aur melakukan Promosi jenis periklanan dalam bentuk brosur-brosur, pemasangan spanduk dan pemasangan baliho, serta souvenirsovenir pada nasabah guna meningkatkan penabung dan jumlah tabungan

\section{Saran- saran}

Berdasarkan kesimpulan yang dapat ditarik dari penelitian ini maka dapat diajukan saran-saran yang kiranya dapat bermanfaat bagi PT. BPR Rangkiang Aur dalam mengembangkan usahanya dimasa yang akan dating yaitu :

1. Selain memberikan hadiah kepada nasabah, ada baiknya memberikan bonus kepada karyawan yang berhasil mencari dan mendapatkan nasabah.

2. Kepada PT. BPR Rangkiang Aur dapat lebih memperhatikan biaya promosi yang dikeluarkan, agar jumlah pengeluaran terminimalisir.

\section{DAFTAR PUSTAKA}

Andika, A., \& Susanti, F. (2018). Pengaruh Marketing Mix Terhadap Keputusan Pembelian Parfum di Azzwars Parfum Lubeg Padang. https://doi.org/10.31227/osf.io/upgc3

Afrianto, D., \& Afriyeni, A. (2019). Aktivitas Penghimpunan Dana Tabungan Pada PT. Bank Pembangunan Daerah (BPD) Sumatera Barat Cabang Utama Padang. https://doi.org/10.31219/osf.io/ackfh

F., \& Afriyeni, A. (2019). Aktivitas Pemasaran Produk Tabungan Pada PT. Bank Pembangunan Daerah (BPD) Sumatera Barat Cabang Utama Padang. https://doi.org/10.31219/osf.io/tf2bz 
Hidayati, R. R., \& Marlius, D. (2018). Aktivitas Promosi Dalam Meningkatkan Dana Pihak Ketiga Pada PT. Bank Perkreditan Rakyat (BPR) Batang Kapas Pesisir Selatan. https://doi.org/10.31227/osf.io/8dgqn

Kasmir, SE, MM, Bank dan Lembaga Keuangan Lainnya, penerbit PT. Raja Grafindo Persada, Jakarta, 2001.

Lupioyadi, Willem, Manajemen Pemasaran Jasa, Penerbit Selemba Empat. Jakarta, 2001.

Marlius, D. (2017). Keputusan Pembelian Berdasarkan Faktor Psikologis Dan Bauran Pemasaran Pada PT. Intercom Mobilindo Padang. Jurnal Pundi. Volume 1. No. 1. Hal. 57-66. https://doi.org/10.31575/jp.v1i1.9

Marlius, D. (2016). Pengaruh Bauran Pemasaran Jasa Terhadap Minat Nasabah Dalam Menabung Pada Bank Nagari Cabang Muaralabuh. https://doi.org/10.31227/osf.io/vdqgx

Marlius, D., \& Putra, R. D (2018). Strategi Pengembangan Sulam Bayang. Jurnal Benefita: Ekonomi Pembangunan, Manajemen bisnis dan akuntansi. Volume 3. Nomor 2. Hal. 204-218. http://doi.org/10.22216/jbe.v3i2.3494

Murti Sumarni “Marketing Perbankan”, Edisi 2, Penerbit Erlangga, Yogyakarta, $2000: 162$.

Philip Kotler. Manajemen Pemasaran II. Penerbit PT. Prehalindo. Edisi Millenium. Jakarta. 2002

Rhegnal Kasali “ Membidik Pasar Indonesia“ Trageting, Positioning”, Penerbit PT. Gramedia Pustaka Utama, Jakarta 2002.

Safitri, R. N., \& Marlius, D. (2017). Penerapan E-Banking Dalam Meningkatkan Jasa Dan Layanan Perbankan Di PT. Bank Rakyat Indonesia Cabang Padang. https://doi.org/10.31227/osf.io/gkv8t

Sarwoto. Dasar-dasar Organisasi dan Manajemen. Penerbit Ghalia. Jakarta.

Sinungan, Murchdiansyah, Manajemen Dana Bank, Penerbit Bumi Aksara, Jakarta, 1993.

Staton J William, Prinsip Pemasaran, Edisi ke 7, jilid 2, Penerbit Erlangga 1986

Sukanto R dan T. Hani Handoko. Teori dan Perilaku Organisasi Perusahaan. Penerbit BPFE. Yogyakarta. 1994. 
Susanti, F. (2015). Pengaruh Bauran Promosi Terhadap Keputusan Klien Dalam Memilih Radio Carano Sebagai Media Promosi Iklan. https://doi.org/10.31227/osf.io/b9ws7

Susanti, F. (2014). Pengaruh Tarif Iklan Terhadap Pendapatan Pada PT. Radio Swara Carano Batirai Indah Batusangkar. https://doi.org/10.31227/osf.io/dy863

Susanti, F. (2018). Faktor Faktor Yang Mempengaruhi Minat Beli Pada ECommerce Lazada.co.id (Studi Pada Mahasiswa Jurusan S1 Manajemen “STIE KBP” Padang). https://doi.org/10.31227/osf.io/um4yw

Undang-undang RI No. 10 Tahun 1998. Tentang Perbankan. Penerbit Sinar Grafika. Cetakan Kedua. 1999.

Wahyuni, S. V., \& Afriyeni, A. (2019). Aktivitas Penghimpunan Dana Deposito Pada PT. Bank Pembangunan Daerah (BPD) Sumatera Barat Cabang Lintau. https://doi.org/10.31219/osf.io/g67d2

Widayati, R. (2019). Promotional Activities And Services Bank Nagari Kambang Increase In Customer. https://doi.org/10.17605/OSF.IO/MYAVT

Widayati, R. (2019). Aktivitas Pemasaran Produk Simpanan PT. Bank Tabungan Negara (Persero)Tbk Kantor Cabang Padang. https://doi.org/10.17605/OSF.IO/3Z5YC

Widayati, R. (2019). Aktivitas Pemasaran Produk Tabungan Pada PT. Bpr Rangkiang Denai Payakumbuh Barat. https://doi.org/10.17605/OSF.IO/S3UZM 